\title{
Entre constrangimentos e vontades: casamentos entre escravizados em Porto Alegre (1772-1850)
}

\author{
Ana Silvia Volpi Scott* \\ Dario Scott ${ }^{\star *}$
}

Os estudos sobre a escravidão vêm demonstrando que o acesso ao casamento entre os cativos estava longe de constituir a regra. Aliás, mesmo para a população livre, parte dos homens e das mulheres jamais teria a sua união formalizada. Aqui explora-se o universo minoritário dos matrimônios entre escravizados realizados na freguesia Nossa Senhora da Madre de Deus de Porto Alegre, Capitania-Província do Rio Grande de São Pedro, entre 1772 e 1850, como mote para discutir a questão dos regimes demográficos restritos, tema importante da pauta da demografia histórica brasileira. As fontes principais são os assentos paroquiais de casamentos, batismos e óbitos de escravizados, analisados a partir de uma perspectiva agregada - perfil dos nubentes, naturalidade, (i)legitimidade -, assim como por meio do estudo das senzalas de dois proprietários que permitiram o casamento de escravizados. Os resultados confirmam o acesso limitado dos escravizados ao casamento formalizado, bem como indicam o impacto do tráfico nos indicadores demográficos, sobretudo a queda muito significativa da fecundidade legítima, com a entrada de escravizados adultos, especialmente a partir da segunda década do século XIX. Por fim, são analisadas duas senzalas, para exemplificar políticas senhoriais que incentivavam o casamento e a reprodução endógena.

Palavras-chave: Escravidão. Regime demográfico. Cruzamento de fontes. Casamento. (I)legitimidade.

\footnotetext{
*Universidade Estadual de Campinas (Unicamp), Campinas-SP, Brasil (anascott@unicamp.br; 0000-0002-0439-070X).

** Pesquisador autônomo (dariostt@gmail.com; 0000-0002-7749-7719).
} 


\section{Introdução}

Embora a historiografia produzida nas duas últimas décadas sobre o Rio Grande de São Pedro, colonial e imperial, tenha avançado muito no estudo do segmento cativo e das famílias formadas entre escravizados (XAVIER, 2007; MOREIRA; PINTO, 2014), pouco se tem produzido no sentido de discutir a questão relativa aos regimes demográficos vigentes no passado brasileiro, tomando como aporte teórico central as propostas de Maria Luiza Marcílio (1984) e Sergio Nadalin (2003, 2004, 2014).

Essa discussão é fundamental, pois o principal conceito da demografia é o de regime demográfico, um arcabouço conceitual construído para entender como os processos históricos impulsionaram as variáveis demográficas e como, por sua vez, foram influenciados por elas (MOURA FILHO, 2021).

Nessa linha, o conceito de "regime demográfico", proposto por Robert Rowland (1997), foi o ponto de partida para estas reflexões. 0 autor argumenta que os comportamentos demográficos não se verificavam num vácuo e seu enquadramento social - sobretudo no âmbito do sistema familiar - tinha importância decisiva para a determinação das dinâmicas demográficas. Tais pressupostos assumem maior relevância quando se analisa uma sociedade tão desigual e hierarquizada como a do Brasil colonial e imperial, marcada pela presença estrutural da escravidão e pela pluralidade de arranjos familiares.

Entre nós, a reflexão sobre a temática dos regimes ou sistemas demográficos ${ }^{1}$ remonta aos estudos pioneiros de Maria Luiza Marcílio, publicados na década de 1980. A autora propunha a existência de quatro sistemas demográficos para o Brasil do século XIX: sistema demográfico das economias de subsistência; sistema demográfico das economias das plantations; sistema demográfico das populações escravas; e sistema demográfico das áreas urbanas (MARCílIO, 1984).

Duas décadas depois, Sergio Nadalin revisitou a tipologia de Marcílio, propondo o mapeamento e a coexistência de vários regimes demográficos restritos, ${ }^{2}$ que teriam vigorado ao longo do período colonial ${ }^{3}$ e se estendido, pelo menos, até meados do século XIX (NADALIN, 2003, 2004, 2014) 4 .

\footnotetext{
${ }^{1}$ Sistema e regime demográfico são considerados sinônimos. Para uma discussão sobre esse tema, ver Cunha (2012).

20 conceito de regime demográfico restrito, de acordo com Philip Kreager (apud CUNHA, 2009, p. 6), vincula-se à forma como grupos fazem uso seletivo dos processos vitais para enfrentar circunstâncias limitadas e à capacidade para continuar a tomar decisões em face do que aparece, pelo menos para seus propósitos práticos imediatos.

${ }^{3}$ A proposição de Nadalin (2004, p. 133-142) inclui a coexistência de dez diferentes regimes, com características específicas: regime demográfico "paulista"; regime demográfico das "plantations"; regime demográfico da "elite”; regime demográfico das "sociedades campeiras"; regime demográfico das "economias de subsistência"; regime demográfico das "drogas do sertão"; regime demográfico das "secas do sertão"; regime demográfico "restrito aos colonos açorianos"; regime demográfico das "economias urbanas"; e regime demográfico da escravidão.

${ }^{4}$ Outra discussão interessante sobre o conceito de regime demográfico encontra-se em Cunha (2012). Mais recentemente, Moura Filho (2021) também trouxe elementos adicionais para discutir a questão dos regimes demográficos no Brasil oitocentista, integrados à "segunda escravidão" (TOMICH, 2020, p. 13 e seg.), no contexto que antecede o fim do tráfico atlântico de escravizados e no momento posterior à sua proibição, a partir de 1850.
} 
0 enfoque que nos interessa restringe-se à coexistência do regime demográfico das economias urbanas e do regime demográfico das populações escravas, o que será analisado a partir do caso da freguesia Madre de Deus de Porto Alegre, que deu origem à capital do atual estado do Rio Grande do Sul. Além de se consolidar como espaço urbano já na virada do século XVIII para o XIX, Porto Alegre também foi definida como uma "cidade negra", diante da significativa presença de escravizados (GOMES, 2012).

Em relação ao regime demográfico das áreas urbanas, Nadalin (2004) manteve os pressupostos lançados por Marcílio, partindo do princípio de que o sistema demográfico de áreas com densidade populacional mais elevada apresentava aspectos diferenciados, opondo-se aos sistemas demográficos das zonas rurais (MARCílIO, 1984, p. 202-203).

0 regime específico das áreas urbanas seria encontrado, preferencialmente, nas cidades-capitais regionais, que desempenhavam funções administrativas, portuárias, comerciais e religiosas. Esses núcleos urbanos também se caracterizariam pela especialização maior e mais variada da força de trabalho, tanto livre como escrava. Em relação às componentes demográficas, a mortalidade seria caracterizada por alta frequência de crises de mortalidade, propagação de epidemias e, mesmo em tempos normais (ausência de crises/epidemias), os níveis de mortalidade seriam superiores aos da natalidade; a natalidade do segmento livre, por sua vez, seria menos elevada do que a das populações rurais, e as uniões consensuais fariam parte do cenário, representadas pelos altos índices de ilegitimidade. Marcílio apontava, ainda, para o caráter intermitente do crescimento vegetativo, e que a população das grandes cidades apresentava crescimento contínuo, sobretudo, em razão das elevadas taxas de imigração. Nas áreas urbanas também a mortalidade infantil apresentava taxas mais elevadas do que nas áreas rurais (tanto de livres quanto de cativos), em função dos constantes problemas de abastecimento e das precárias condições sanitárias e de habitação. Segundo suas estimativas, nos centros urbanos e portuários, a taxa de mortalidade infantil nunca seria inferior a 200 por mil (MARCílIO, 1984, p. 202-207).

De outra parte, Marcílio chamava a atenção para o fenômeno da mobilidade social e da mestiçagem. Por meio da multiplicação da manumissão dos escravos, uma característica mais comum às áreas urbanas do que às rurais, engrossavam-se as estatísticas da população livre, assim como aumentava a presença de segmentos populacionais não brancos (mulatos e mestiços).

Em relação ao regime demográfico das populações escravizadas, Marcílio (1984, p. 201-202) apontava cinco características principais: mortalidade extremamente elevada, especialmente a infantil, para todas as épocas e regiões; alta frequência de surtos epidêmicos devastadores (varíola, cólera-morbo, febre amarela); baixíssimas taxas de nupcialidade, com ausência quase total da família estável e legal; fecundidade geral das mais baixas; e desequilíbrio entre os sexos, com preferência para a importação de homens, resultando no crescimento populacional negativo entre os cativos. 
Amparado pelos avanços em relação ao estudo da escravidão, da família escrava e do tráfico atlântico, Nadalin (2004, p. 133 e seg.) contribuiu para a revisão das características do regime demográfico da escravidão, a partir de quatro elementos principais: sua ligação intrínseca com as flutuações da produção, do tráfico e a continuidade de seu fluxo; o reforço da cultura africana no Brasil; as repercussões da fecundidade, morbidade/mortalidade dos escravos, razão de sexo e estrutura etária da população; e as possibilidades postas pelo casamento, formação de famílias escravas mais ou menos estáveis, que variariam em função das características das próprias senzalas. Apesar da reformulação, a proposta de Nadalin continuava atrelando o regime demográfico das populações escravas ao regime demográfico das plantations (CUNHA, 2012). Nos parece fundamental, nesse momento, avançar para a análise do regime das populações escravizadas, fora do circuito da plantation, enfocando áreas urbanas.

Nunca é demais lembrar que, na condição de escravizados, o acesso ao casamento formalizado era o resultado da somatória de constrangimentos e vontades, sobretudo senhoriais, que teriam papel decisivo na realização, ou não, do casamento consagrado na igreja, ainda que as constituições defendessem que, "conforme o direito divino e humano, os escravos e escravas podem casar com outras pessoas cativas ou livres e seus senhores lhe não podem impedir". ${ }^{5}$ A discussão sobre o acesso dos escravizados ao casamento remonta a estudos publicados desde a década de 1980, entre outros, Schwartz (1988) e Slenes $(1987,1999)$.

Em análise recente, Viana e Gomes (2020) argumentam que os padrões conjugais estavam associados a um conjunto de questões, que iam além da vontade senhorial, apontando para a complexidade envolvida nas opções e constrangimentos a que estavam submetidos os escravizados. Entre as questões levantadas, indagava-se quais seriam as determinações e os impactos das escolhas maritais: seria resultado somente de políticas senhoriais? Haveria influência de homens ou mulheres mais velhos nas escolhas? Haveria diferenças de acordo com as diferentes gerações de escravizados nas diversas comunidades escravas?

Todas essas considerações nos estimulam a refletir sobre o caso dos escravizados que viveram em Porto Alegre, localidade alçada a capital do Rio Grande de São Pedro, no ano de 1773. Embora ela não se compare, em volume da população e importância, a cidades como Salvador, Rio de Janeiro ou Recife, que serviram de mote para Marcílio pensar o regime demográfico das áreas urbanas, Porto Alegre era um destacado espaço urbano portuário, no contexto regional do Brasil Meridional.

Além disso, Porto Alegre se caracterizava pela convivência e ligação entre a área urbana e a rural que a circundava. Desde seu período formativo, também contou com significativa presença de população escravizada (GOMES, 2012). Nas oito décadas analisadas, Porto Alegre atravessou momentos de grande dinamismo populacional e econômico, assim como períodos de instabilidade e dificuldades, sobretudo durante a Guerra dos Farrapos

\footnotetext{
$\overline{{ }^{5} \text { Constituições Primeiras }}$ do Arcebispado da Bahia, Título LXXI, Do matrimônio dos escravos. (VIDE, 2011, p. 125-126).
} 
(1835-1845), quando a cidade permaneceu sitiada. ${ }^{6}$ Além de capital, o seu porto fluvial era a porta de acesso para o interior do território, gerando intensa movimentação de embarcações, pessoas, mercadorias e doenças, encontrando-se estrategicamente localizado, próximo ao estuário do rio Guaíba, dando acesso à Lagoa dos Patos e, consequentemente, à vila de Rio Grande, único porto de mar do extremo sul.

Na primeira metade do século XIX, o contínuo desenvolvimento da localidade foi registrado por vários viajantes, assim como por funcionários da administração. Às vésperas da independência e de sua elevação à condição de cidade (1822), relatos chamavam a atenção para o comércio e as diversas fábricas e oficinas ali instaladas (CHAVES, 2004 [1822]). Mas Porto Alegre também mantinha sua faceta "rural”, com importante produção de gêneros como frutas e trigo, sendo que a triticultura teve o auge de sua produção em 1813 (KÜHN, 2004, 2006). Desse período até o início da Guerra dos Farrapos, a cidade consolidou sua posição de importante centro administrativo e comercial, da então província de São Pedro do Rio Grande do Sul, com uma curva ascendente na evolução da população, tanto livre como escravizada. ${ }^{7}$

Ainda que o decênio da guerra tenha sido de estagnação para toda a província e para a própria capital, dados indicam que, já no final da década de 1850, Porto Alegre havia recuperado o dinamismo de seu comércio que estava vinculado à imigração (PESAVENTO, 1999, 2009). A historiografia reconhece a importância da comercialização de gêneros variados, produzidos nos territórios onde se estabeleceram os imigrantes alemães, a partir da década de 1820 . Sob o raio de abrangência do porto de Porto Alegre, centralizava-se a coleta dessa produção, a sua exportação, assim como a importação dos bens requeridos pelas novas populações que ali se fixaram (SOUZA; MÜLLER, 2007).

A análise da evolução populacional mostra que, até meados do século XIX, tanto a população livre quanto a escravizada mantiveram tendência de aumento. A inflexão nessa curva se manifestou para a população escravizada somente a partir da segunda metade do XIX, possivelmente vinculada ao fim do tráfico atlântico de africanos, em 1850 (Gráfico 1).

Em termos de sua distribuição por condição jurídica, verifica-se que, em média, o segmento livre girava em torno de $66 \%$ do total e a população escravizada alcançava $34 \%$. No entanto, ao longo do tempo, registrou-se em Porto Alegre o decréscimo significativo da participação dos escravizados no montante geral de seus habitantes: em 1798, os cativos perfaziam $42 \%$ da população total, enquanto no final do período somavam apenas $29 \%$ (SCOTT, 2020).

\footnotetext{
${ }_{6}$ Para uma análise mais aprofundada do contexto de Porto Alegre, colonial e imperial, ver Dario Scott (2020).

${ }^{7}$ Ao longo dos cem anos entre 1772 e 1872, o crescimento sustentado da população só teve inflexão a partir de 1848, seja como reflexo da difícil situação da guerra, seja pelo desmembramento efetivo da Madre de Deus, única freguesia na cidade de Porto Alegre até 1844, quando se iniciaram os registros paroquiais para a freguesia de Nossa Senhora do Rosário. Posteriormente, a partir de 1859, já encontramos os registros para a freguesia Nossa Senhora das Dores, embora o Decreto Regencial que determinava a divisão seja datado de 24 de outubro de 1832 (SCOTT, 2020).
} 
GRÁFICO 1

Evolução da população livre e escrava

Freguesia Nossa Senhora da Madre de Deus - 1772-1872

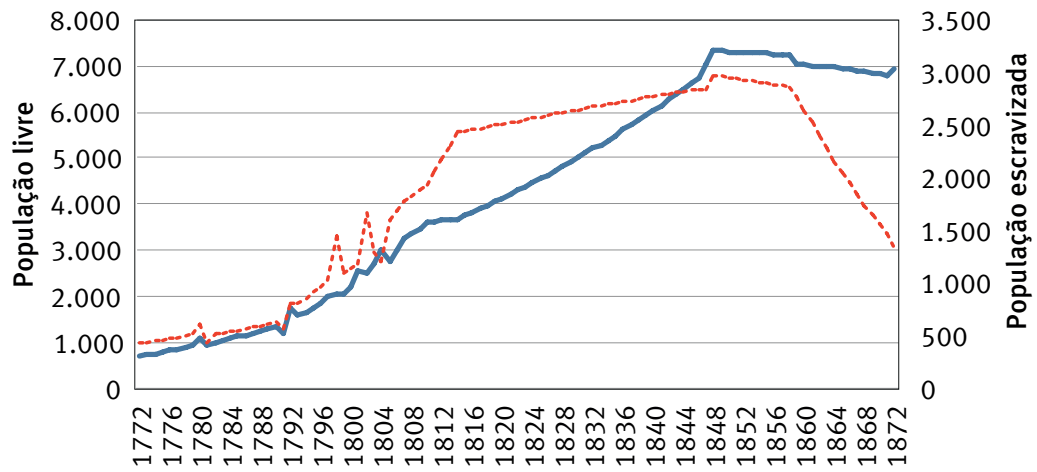

Livres ...... Escravizados

Fonte: Scott (2020).

Conhecer as características demográficas da população de Porto Alegre é fundamental para enquadrar essa discussão, considerando a coexistência dos regimes demográficos das áreas urbanas e das populações escravizadas. Para se pensar sobre o casamento e a reprodução dos escravizados no contexto desse núcleo urbano e suas cercanias rurais, devemos levar em conta não apenas a faceta mais conhecida do acesso restrito dos escravizados ao casamento formal e as altas taxas de ilegitimidade, mas também os indicadores relativos à mortalidade que afetava toda a sua população, incluindo a escravizada.

0 perfil da mortalidade sofreu alterações no decorrer do tempo atreladas ao processo histórico de consolidação da localidade como importante núcleo urbano regional, ao volume e à estrutura da população, no período analisado, registrando inclusive aumento da taxa de mortalidade. Para os escravizados, a taxa bruta de mortalidade (TBM) variou entre 80,1 por mil (1800-1819) e 101,6 por mil (1820-1849), enquanto a da população livre ficou entre 53,2 por mil e 59,5 por mil, respectivamente. Da mesma maneira, tanto para os escravizados quanto para a população livre, as taxas de mortalidade infantil mantiveram-se muito elevadas, ultrapassando 300 por mil nascidos vivos. Registrou-se, por outro lado, 0 aumento da esperança de vida ao nascer dos escravizados: de 17,1 para 24,4 anos, para homens, e de 21,5 para 28,4 anos, para mulheres. Para a população livre, como esperado, a esperança de vida ao nascer era maior do que a dos escravos - a masculina passou de 19,1 (1779-1782) para 30,3 anos (1859-1872) e a feminina de 26,6 para 34,8 anos, no mesmo período (SCOTT, 2020). Tanto as mulheres livres quanto as escravizadas tinham uma esperança de vida ao nascer maior do que a dos homens.

Esses resultados revelam que a população livre e a escravizada enfrentavam condições sanitárias muito precárias, características do chamado período pré-transicional, o que fez com que ambos os segmentos populacionais padecessem praticamente das mesmas 
doenças, com predomínio das moléstias infectocontagiosas, especialmente a diarreia e enterite, varíola, sarampo e tuberculose (SCOTT, 2020). Sem dúvida, esse quadro demográfico, de alta mortalidade e de baixa esperança de vida ao nascer, teve desdobramentos importantes na vida de todos os habitantes, especialmente entre os escravizados e nas possibilidades de acesso à família. Mais do que isso, corroboram as características de mortalidade apontadas para os regimes demográficos restritos propostos por Marcílio e Nadalin.

É, portanto, nesse largo intervalo temporal de quase 80 anos que analisaremos 0 acesso de escravizados ao casamento formal, abordando os constrangimentos e limites aos quais estavam submetidas as populações escravizadas, a partir da exploração dos dados coletados para Porto Alegre. Ainda é importante lembrar que cidade e campo, naquele período, não podem ser considerados polos opostos (MARCílIO, 1984, p. 203; SCHWARTZ, 1988, p. 245).

\section{Fonte de dados e metodologia}

O conjunto de dados que constituem o ponto de partida são 312 assentos de casamentos realizados na Madre de Deus, entre 1772 e 1850, nos quais todos os nubentes envolvidos eram cativos, assim como o conjunto de assentos de batismo de crianças escravas legítimas, registrados nos livros da mesma paróquia, que reúnem 864 batizados ( 439 crianças do sexo feminino e 425 do masculino). Foram usados ainda os assentos de óbito. Esses dados serão examinados no contexto geral da população escravizada, bem como no da população livre, quando isso for pertinente. Cada casamento entre escravizados teria gerado, em média, quase três filhos $(2,8)$.

Procuramos discutir aspectos do comportamento matrimonial e reprodutivo da população cativa de Porto Alegre, apresentando o perfil dos nubentes, assim como procuramos acompanhar, quando foi possível, a trajetória reprodutiva de alguns desses casais, por meio do cruzamento com os assentos de batismo e óbito de escravos para este intervalo temporal. 0 cruzamento nominativo das informações coletadas nos assentos paroquiais foi usado, tendo como fio condutor os nomes de seus proprietários, assinalados nos respectivos assentos. Assim, tivemos a oportunidade de recolher os dados relativos aos escravos que se casaram e batizaram rebentos na localidade, o que forneceu elementos para tratar as características demográficas e familiares da escravidão urbana, ainda que se admitam os "limites" dessa urbanização e a estreita relação com o entorno rural da capital, no contexto do Rio Grande de São Pedro no período.

\section{Nascer na Madre de Deus: escravizados e escravizadas na pia batismal}

Vários são os estudos, de norte a sul do Brasil, que vêm analisando a questão da (i)legitimidade entre a população escravizada (SLENES, 1987, 1999; FARIA, 1992, 1998; 
SLENES; FARIA, 1998; BRÜGGER, 2000, 2007; CUNHA, 2005, 2009; FREIRE, 2005, 2009; PETIZ, 2020, entre outros).

Uma análise sobre a região centro-sul do Brasil, na primeira metade do século XIX, aponta para o aumento da ilegitimidade entre os escravizados, entre os meados do século XVIII e meados do XIX. Várias foram as hipóteses explicativas para o fenômeno: tamanho da escravaria; ambientes rurais ou urbanos; áreas de ocupação e exploração mais antigas ou mais recentes; e expansão das fronteiras agrárias com espaços caracterizados por maior instabilidade (LIMA, 2013).

No caso do Rio Grande de São Pedro, há vários estudos que mostram a presença significativa da ilegitimidade nas várias partes do território meridional, consequência direta do acesso limitado dos escravizados e escravizadas ao casamento formalizado na igreja. 0 caso de Rio Pardo, situado na área da fronteira oeste, desde meados do século XVIII até o final do XIX, mostrou isso (PETIZ, 2020; PERUSSATTO, 2010). Altos índices de ilegitimidade entre os escravizados também foram registrados para Cachoeira/ Santa Maria, entre 1798 e 1834 (RIBEIRO, 2013, entre outros estudos).

Para Porto Alegre deve-se assinalar o aumento do volume dos batizados de crianças escravizadas, em relação ao conjunto da população, entre os finais do século XVIII e meados do XIX (Tabela 1). 0 aumento do número absoluto de batizados pode se justificar pelo dinamismo que a região alcançou no decorrer do período (BERUTE, 2006). No entanto, o que mais chama a atenção é o aumento do percentual de batizados de escravos em relação aos livres. ${ }^{8}$

Se deixarmos de lado os anos que seguem a criação da freguesia, 1772-1774, verificamos que, dos 387 assentos de batismo registrados pelos párocos, cerca de dois terços eram de crianças livres. Para o período todo, a média de batismos de escravizados fica acima dos 34\%. Apesar de algumas flutuações, há que se destacar a tendência geral de crescimento, que só teve pequeno refluxo no quinquênio 1835-39, já em pleno conflito Farroupilha. É importante lembrar que Porto Alegre permaneceu sob o cerco dos rebeldes até 1840 , fato que, curiosamente, teve pouco impacto sobre o ritmo dos batizados de escravizados e, absolutamente, não se fez sentir entre a população livre que, inclusive, apresentou aumento no cômputo geral.

Por sua vez, a ilegitimidade atingia índices significativos entre todas as crianças batizadas, livres e cativas. Os dados sobre a legitimidade deixam explicitada, mais uma vez, a restrição ao casamento sacramentado na igreja de parcelas da população, tanto livre quanto cativa, fato que não era exclusividade de Porto Alegre, especialmente quanto às crianças escravizadas.

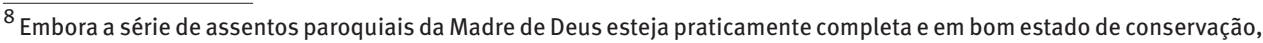
chamamos a atenção para duas lacunas na série de batizados: em 1818 e 1819 para os batismos de escravos (veja-se a queda no percentual para o quinquênio 1815-1819) e para os livres, entre 1849 e 1850. Nesse último caso, pode explicar a diferença importante entre batizados de livres e escravos em 1850
} 
TABELA 1

Distribuição dos batizados, por condição jurídica Freguesia Nossa Senhora da Madre de Deus - 1772-1850

\begin{tabular}{|c|c|c|c|c|c|}
\hline \multirow{3}{*}{ Período } & \multicolumn{5}{|c|}{ Batizados } \\
\hline & \multicolumn{2}{|c|}{ Livres } & \multicolumn{2}{|c|}{ Escravizados } & \multirow{2}{*}{ Total } \\
\hline & $\mathrm{N}$ & $\%$ & $\mathrm{~N}$ & $\%$ & \\
\hline $1772-74$ & 83 & 71,6 & 33 & 28,4 & 116 \\
\hline $1775-79$ & 258 & 66,7 & 129 & 33,3 & 387 \\
\hline $1780-84$ & 357 & 72,7 & 134 & 27,3 & 491 \\
\hline $1785-89$ & 413 & 67,4 & 200 & 32,6 & 613 \\
\hline $1790-94$ & 573 & 72,4 & 218 & 27,6 & 791 \\
\hline $1795-99$ & 712 & 59,5 & 485 & 40,5 & 1.197 \\
\hline $1800-04$ & 869 & 65,2 & 464 & 34,8 & 1.333 \\
\hline 1805-09 & 1.053 & 69,7 & 458 & 30,3 & 1.511 \\
\hline $1810-14$ & 1.352 & 69,4 & 596 & 30,6 & 1.948 \\
\hline $1815-19$ & 1.505 & 73,4 & 545 & 26,6 & 2.050 \\
\hline $1820-24$ & 1.753 & 64,1 & 981 & 35,9 & 2.734 \\
\hline $1825-29$ & 2.012 & 63,4 & 1160 & 36,6 & 3.172 \\
\hline $1830-34$ & 2.255 & 64,0 & 1266 & 36,0 & 3.521 \\
\hline $1835-39$ & 1.844 & 66,8 & 918 & 33,2 & 2.762 \\
\hline $1840-44$ & 2.193 & 68,0 & 1031 & 32,0 & 3.224 \\
\hline $1845-49$ & 1.251 & 58,1 & 902 & 41,9 & 2.153 \\
\hline 1850 & 49 & 22,2 & 172 & 77,8 & 221 \\
\hline Total & 18.532 & 65,7 & 9.692 & 34,3 & 28.224 \\
\hline
\end{tabular}

Fonte: Dados Nacaob - Madre de Deus de Porto Alegre (março de 2021).

Para São João del Rei, Minas Gerais, entre a primeira metade do XVIII e a primeira metade do XIX, Brügger (2000) encontrou oscilações que indicam que a legitimidade das crianças cativas poderia variar entre $20 \%$ (1736-1750) e cerca de 40\% (1780-1810), ou despencar para 15\%, a partir de 1830-1850. Variações de legitimidade também foram registradas para a vila de Franca, São Paulo, ao longo do século XIX: 45\% no período 1806-1850; 51\% em 1851-1871; caindo para 37\%, entre 1872 e 1888 (CUNHA, 2009). 0 caso de Senhor Jesus do Rio Pardo (MG) também mostrou alto grau de ilegitimidade para todo o período entre 1838 e 1887, com 70\% de batismo de escravos naturais (FREIRE, 2005).

A ilegitimidade é, portanto, um elemento a se considerar na análise dos regimes demográficos vigentes, como advertiram Marcílio e Nadalin. Examinemos cada uma das categorias no caso de Porto Alegre, ao longo das oito décadas analisadas.

Desagregando os dados do conjunto dos batizados de crianças livres (18.532), subdivididos por legitimidade (Tabela 2), temos 13.690 assentos de crianças livres nascidas de uniões consagradas na igreja, revelando a supremacia dos assentos de crianças legítimas, com $73,9 \%$, acompanhadas por $26,1 \%$ de assentos distribuídos pelas categorias de naturais e expostos ( $20,2 \%$ e $4,6 \%$, respectivamente) e um resíduo de cerca de $1,4 \%$ de assentos em que a condição de legitimidade não foi informada. 
TABELA 2

Legitimidade dos batizados na população livre Freguesia Nossa Senhora da Madre de Deus - 1772-1850

\begin{tabular}{|c|c|c|c|c|c|c|c|c|c|}
\hline \multirow{2}{*}{ Período } & \multicolumn{2}{|c|}{ Legítimos } & \multicolumn{2}{|c|}{ Naturais } & \multicolumn{2}{|c|}{ Expostos } & \multicolumn{2}{|c|}{ Não declarados } & \multirow{2}{*}{ Total } \\
\hline & $\mathrm{N}$ & $\%$ & $\mathrm{~N}$ & $\%$ & $\mathrm{~N}$ & $\%$ & $\mathrm{~N}$ & $\%$ & \\
\hline $1770-74$ & 72 & 86,7 & 4 & 4,8 & 1 & 1,2 & 6 & 7,2 & 83 \\
\hline $1775-79$ & 218 & 84,5 & 29 & 11,2 & 6 & 2,3 & 5 & 1,9 & 258 \\
\hline $1780-84$ & 315 & 88,2 & 33 & 9,2 & 7 & 2,0 & 2 & 0,6 & 357 \\
\hline $1785-89$ & 347 & 84,0 & 45 & 10,9 & 21 & 5,1 & & 0,0 & 413 \\
\hline $1790-94$ & 482 & 84,1 & 71 & 12,4 & 18 & 3,1 & 2 & 0,3 & 573 \\
\hline $1795-99$ & 559 & 78,5 & 115 & 16,2 & 37 & 5,2 & 1 & 0,1 & 712 \\
\hline $1800-04$ & 676 & 77,8 & 127 & 14,6 & 51 & 5,9 & 15 & 1,7 & 869 \\
\hline $1805-09$ & 810 & 76,9 & 168 & 16,0 & 69 & 6,6 & 6 & 0,6 & 1.053 \\
\hline $1810-14$ & 1.006 & 74,4 & 253 & 18,7 & 87 & 6,4 & 6 & 0,4 & 1.352 \\
\hline 1815-19 & 1.060 & 70,4 & 310 & 20,6 & 116 & 7,7 & 19 & 1,3 & 1.505 \\
\hline $1820-24$ & 1.237 & 70,6 & 365 & 20,8 & 137 & 7,8 & 14 & 0,8 & 1.753 \\
\hline $1825-29$ & 1.458 & 72,5 & 433 & 21,5 & 111 & 5,5 & 10 & 0,5 & 2.012 \\
\hline $1830-34$ & 1.614 & 71,6 & 530 & 23,5 & 99 & 4,4 & 12 & 0,5 & 2.255 \\
\hline $1835-39$ & 1.389 & 75,3 & 390 & 21,1 & 48 & 2,6 & 17 & 0,9 & 1.844 \\
\hline $1840-44$ & 1.599 & 72,9 & 524 & 23,9 & 34 & 1,6 & 36 & 1,6 & 2.193 \\
\hline $1845-49$ & 822 & 65,7 & 327 & 26,1 & 8 & 0,6 & 94 & 7,5 & 1.251 \\
\hline 1850 & 26 & 53,1 & 13 & 26,5 & & 0,0 & 10 & 20,4 & 49 \\
\hline Total & 13.690 & 73,9 & 3.737 & 20,2 & 850 & 4,6 & 255 & 1,4 & 18.532 \\
\hline
\end{tabular}

Fonte: Dados Nacaob - Madre de Deus de Porto Alegre (março de 2021).

TABELA 3

Legitimidade dos batizados na população cativa Freguesia Nossa Senhora da Madre de Deus - 1772-1850

\begin{tabular}{|c|c|c|c|c|c|c|c|}
\hline \multirow{2}{*}{ Período } & \multicolumn{2}{|c|}{ Legítimos } & \multicolumn{2}{|c|}{ Naturais } & \multicolumn{2}{|c|}{ Não declarados } & \multirow{2}{*}{ Tota } \\
\hline & $\mathrm{N}$ & $\%$ & $\mathrm{~N}$ & $\%$ & $\mathrm{~N}$ & $\%$ & \\
\hline $1770-74$ & 6 & 18,2 & 27 & 81,8 & & 0,0 & 33 \\
\hline $1775-79$ & 35 & 27,1 & 94 & 72,9 & & 0,0 & 129 \\
\hline $1780-84$ & 30 & 22,4 & 104 & 77,6 & & 0,0 & 134 \\
\hline $1785-89$ & 40 & 20,0 & 159 & 79,5 & 1 & 0,5 & 200 \\
\hline $1790-94$ & 48 & 22,0 & 148 & 67,9 & 22 & 10,1 & 218 \\
\hline $1795-99$ & 92 & 19,0 & 358 & 73,8 & 35 & 7,2 & 485 \\
\hline $1800-04$ & 65 & 14,0 & 385 & 83,0 & 14 & 3,0 & 464 \\
\hline 1805-09 & 83 & 18,1 & 369 & 80,6 & 6 & 1,3 & 458 \\
\hline $1810-14$ & 90 & 15,1 & 492 & 82,6 & 14 & 2,3 & 596 \\
\hline $1815-19$ & 54 & 9,9 & 399 & 73,2 & 92 & 16,9 & 545 \\
\hline $1820-24$ & 72 & 7,3 & 673 & 68,6 & 236 & 24,1 & 981 \\
\hline $1825-29$ & 65 & 5,6 & 742 & 64,0 & 353 & 30,4 & 1.160 \\
\hline $1830-34$ & 64 & 5,1 & 860 & 67,9 & 342 & 27,0 & 1.266 \\
\hline $1835-39$ & 58 & 6,3 & 734 & 80,0 & 126 & 13,7 & 918 \\
\hline $1840-44$ & 51 & 4,9 & 779 & 75,6 & 201 & 19,5 & 1.031 \\
\hline $1845-49$ & 9 & 1,0 & 526 & 58,3 & 367 & 40,7 & 902 \\
\hline 1850 & 2 & 1,2 & 116 & 67,4 & 54 & 31,4 & 172 \\
\hline Total & 864 & 8,9 & 6.965 & 71,9 & 1.863 & 19,2 & 9.692 \\
\hline
\end{tabular}

Fonte: Dados Nacaob - Madre de Deus de Porto Alegre (março de 2021). 
A significativa elevação desse conjunto de batizados (especialmente a partir de 1815) teve impacto direto na queda dos percentuais de legitimidade (Tabela 3). Até o final do século XVIII, havia mais de $20 \%$ das crianças cativas legítimas. Paulatinamente, a partir do início do século XIX, ocorreu consistente diminuição desses patamares de legitimidade, caindo para escassos $5 \%$ ou $6 \%$ dos batismos de crianças escravas legítimas entre 1830 e 1839. Essa redução continuou até os anos finais do período analisado, quando passaram a ser residuais os batizados de crianças escravizadas legítimas (em torno de 1\%, entre 1845 e 1849).

Fato também muito interessante é o número crescente de batizados em que não se declara a legitimidade do cativo (N/D). 0 que estaria por trás disso? A explicação para esse comportamento veio a partir do cruzamento do dado sobre a condição de ilegitimidade com a idade declarada dos batizandos, informação que era arrolada pelo pároco no registro: no caso dos escravizados para os quais não se conhece a legitimidade, tratava-se daqueles maiores de dez anos, ou como Marcílio os considerava, eram batizados de escravizados adultos, que tinham entre 10 e 12 anos (MARCíLIO, 1984, p.202).

Se no início do século XIX (1800-1819) o percentual médio desses casos girava em torno de $4 \%$, entre 1820 e 1829 saltou para $27,5 \%$, continuando a aumentar nos anos seguintes: $29,4 \%$ entre $1840-49$, atingindo o ápice de $31,4 \%$ em 1850 . Nos anos seguintes, retomou a tendência de queda, talvez como desdobramento da lei de 07 de novembro de 1831 , que, sob a pressão da Inglaterra, pretendia impor o fim do tráfico negreiro. Às vésperas do fim do tráfico atlântico houve sensível aumento da entrada de escravizados adultos, batizados na igreja da Madre de Deus, alcançando mais de $40 \%$ dos assentos registrados.

A análise das características dos escravizados adultos que entraram entre 1815 e 1850 revelou que a razão de sexo entre aqueles com dez anos ou mais era da ordem de 180 homens para cada 100 mulheres. ${ }^{9}$ Mais uma vez percebemos atributos do regime demográfico das populações escravas em Porto Alegre: desequilíbrio entre os sexos, com predomínio dos homens jovens e em idade produtiva, que alimentavam a força de trabalho, a partir do tráfico, também em uma área urbana. 0 vínculo do Rio Grande de São Pedro ${ }^{10}$ com o tráfico de escravos (via Rio de Janeiro em direção ao porto de Rio Grande), entre o final do século XVIII e as primeiras décadas do XIX, foi pormenorizadamente tratado por Gabriel Berute (2006), comprovando que também naquela região predominava a entrada de africanos do sexo masculino. 0 autor mostrou ainda que a importação desses escravos acompanhou a tendência de aceleração verificada no tráfico, no período analisado (1790-1825).

\footnotetext{
${ }^{9}$ Para o conjunto dos batizados a razão de sexos é 104.

${ }^{10}$ Ainda que fosse uma região caracterizada como economia não exportadora, voltada para o mercado interno (BERUTE, 2006).
} 


\section{Casar-se na Madre de Deus: os escravizados e escravizadas sobem ao altar}

A questão do acesso dos escravizados ao casamento foi analisada por inúmeros estudiosos. No final da década de 1990, Robert Slenes (1999) apontava que, para a província de São Paulo, as taxas de casamento eram superiores às do Rio de Janeiro, por conta da maior presença da igreja em São Paulo. Slenes atribuía esses contrastes a diferenças culturais dos proprietários, afirmando que, em São Paulo, os senhores possuíam um compromisso maior com a formalização dos casamentos de seus escravizados, afirmação que, a nosso ver, é discutível.

De toda sorte, os estudos sobre o casamento entre escravizados revelam que a união sancionada se dava, quase sempre, entre cativos pertencentes ao mesmo proprietário, preferencialmente entre escravizados da mesma origem ou nação africana, sendo poucos os matrimônios que uniam escravizados com pessoas de outro estatuto jurídico (FREIRE, 2005, 2009).

A Tabela 4 reúne informações sobre todos os casamentos realizados na Madre de Deus, apresentando a sua distribuição por quinquênios e de acordo com a condição jurídica dos nubentes. Essa opção facilita a análise comparada entre o acesso de livres e cativos ao sacramento do matrimônio. Entre 1772 e 1850, somaram 4.320 registros.

TABELA 4

Casamentos, por condição jurídica

Freguesia Nossa Senhora da Madre de Deus - 1772-1850

\begin{tabular}{|c|c|c|c|c|c|c|c|c|c|}
\hline \multirow{2}{*}{ Período } & \multicolumn{2}{|c|}{ Livres com livres } & \multicolumn{2}{|c|}{ Forros com forros } & \multicolumn{2}{|c|}{$\begin{array}{c}\text { Escravizados com } \\
\text { escravizados }\end{array}$} & \multicolumn{2}{|c|}{ Mistos } & \multirow[t]{2}{*}{ Total } \\
\hline & $\mathrm{N}$ & $\%$ & $\mathrm{~N}$ & $\%$ & $\mathrm{~N}$ & $\%$ & $\mathrm{~N}$ & $\%$ & \\
\hline $1772-74$ & 38 & 84,4 & & 0,0 & 4 & 8,9 & 3 & 6,7 & 45 \\
\hline $1775-79$ & 51 & 68,9 & 7 & 9,5 & 13 & 17,6 & 3 & 4,1 & 74 \\
\hline $1780-84$ & 69 & 87,3 & 1 & 1,3 & 6 & 7,6 & 3 & 3,8 & 79 \\
\hline $1785-89$ & 88 & 80,7 & & 0,0 & 16 & 14,7 & 5 & 4,6 & 109 \\
\hline $1790-94$ & 150 & 83,8 & 4 & 2,2 & 20 & 11,2 & 5 & 2,8 & 179 \\
\hline $1795-99$ & 129 & 82,2 & & 0,0 & 26 & 16,6 & 2 & 1,3 & 157 \\
\hline $1800-04$ & 218 & 83,8 & 1 & 0,4 & 40 & 15,4 & 1 & 0,4 & 260 \\
\hline $1805-09$ & 237 & 78,0 & 14 & 4,6 & 33 & 10,9 & 20 & 6,6 & 304 \\
\hline $1810-14$ & 215 & 78,5 & 19 & 6,9 & 31 & 11,3 & 9 & 3,3 & 274 \\
\hline $1815-19$ & 237 & 83,7 & 16 & 5,7 & 19 & 6,7 & 11 & 3,9 & 283 \\
\hline $1820-24$ & 322 & 88,7 & 6 & 1,7 & 22 & 6,1 & 13 & 3,6 & 363 \\
\hline $1825-29$ & 414 & 88,8 & 13 & 2,8 & 26 & 5,6 & 13 & 2,8 & 466 \\
\hline $1830-34$ & 479 & 90,9 & 16 & 3,0 & 23 & 4,4 & 9 & 1,7 & 527 \\
\hline $1835-39$ & 277 & 92,0 & 16 & 5,3 & 7 & 2,3 & 1 & 0,3 & 301 \\
\hline $1840-44$ & 448 & 92,9 & 18 & 3,7 & 9 & 1,9 & 7 & 1,5 & 482 \\
\hline $1845-49$ & 319 & 94,4 & 9 & 2,7 & 7 & 2,1 & 3 & 0,9 & 338 \\
\hline 1850 & 68 & 86,1 & & 0,0 & 10 & 12,7 & 1 & 1,3 & 79 \\
\hline Total & 3.759 & 87,0 & 140 & 3,2 & 312 & 7,2 & 109 & 2,5 & 4.320 \\
\hline
\end{tabular}

Fonte: Dados Nacaob - Madre de Deus de Porto Alegre (março 2021). 
A maioria dos assentos envolveu indivíduos da mesma condição, ou seja, um padrão de endogamia jurídica - noivos livres com livres, escravizados com escravizados, forros com forros, assim distribuídos: $87 \%$ de matrimônio entre noivos livres; 7,2\% entre escravizados; e 3,2\% de casos em que ambos eram forros. Em apenas 2,5\% dos casamentos registrados na Madre de Deus os noivos tinham condição jurídica diferente, o que corresponde a pouco mais de uma centena de casos (SCOTT; SCOTT, 2015). A vila de Franca, São Paulo, também indicou predomínio de casamentos endogâmicos, nas bodas entre nubentes escravizados (CUNHA, 2009), comportamento que se repetiu na generalidade dos estudos sobre o tema.

TABELA 5

Casamentos, segundo condição jurídica dos nubentes Freguesia Nossa Senhora da Madre de Deus - 1772-1850

\begin{tabular}{lrrrr}
\hline \multirow{2}{*}{$\begin{array}{l}\text { Condição jurídica do } \\
\text { noivo }\end{array}$} & \multicolumn{3}{c}{ Condição jurídica da noiva } & \multirow{2}{*}{ Total } \\
\cline { 2 - 4 } & 3.759 & Forra & Escravizada & \\
\hline Livre & 10 & 37 & 7 & 3.803 \\
Forro & 4 & 140 & 23 & 173 \\
Escravizado & 3.773 & 28 & 312 & 344 \\
Total & 205 & 342 & 4.320 \\
\hline
\end{tabular}

Fonte: Dados Nacaob - Madre de Deus de Porto Alegre (março 2021).

Em relação aos “casamentos entre desiguais”, 109 no total (Tabela 4), vale notar que $31,9 \%$ deles uniam homens livres ou forros a mulheres escravizadas, resultando em prole que seguiria em cativeiro (Tabela 5). A mesma proporção foi detectada na situação inversa, em que mulheres livres ou forras se casaram com escravizados (31,7\%), sem o agravante de os filhos gerados pelo casal herdarem a condição de escravizados, já que a prole segue sempre o "ventre da mãe".

Aqui interessa analisar apenas o universo dos casamentos que uniam escravizados, sacramentados na igreja e, quando possível, a família e a prole legítima gerada.

Partiremos da análise seriada e agregada das 312 uniões que envolviam apenas escravizados, consagradas durante o período destacado. Assim, entre 1772 e 1850, registrou-se uma média de quatro casamentos entre nubentes cativos, por ano, enquanto para os cônjuges livres ocorrera, em média, 48 matrimônios por ano. Se juntarmos os casamentos de nubentes forros aos dos livres, somaríamos perto de $95 \%$ do total de uniões registradas nos assentos da paróquia.

Sem dúvida esses números reforçam a ideia de que a nupcialidade era extremamente baixa entre a população cativa da Madre de Deus, o que corrobora a hipótese apresentada, em relação ao regime demográfico da escravidão, de que o acesso ao casamento era altamente restrito entre a população escrava, não apenas onde predominava a plantation, mas também em áreas com características urbanas, como é o caso da freguesia da Madre de Deus de Porto Alegre.

Vejamos também algumas das características dos casamentos que uniram nubentes cativos a partir das informações registradas pelos párocos naqueles assentos, como a 
distribuição por mês e dias da semana, que foram preferencialmente escolhidos para a realização das bodas.

0 Gráfico 2 revela que os meses mais escolhidos para as bodas foram janeiro e novembro. Os escravizados que se casavam respeitavam ainda com mais intensidade os tempos proibidos determinados pela igreja Católica por conta do Advento e da Quaresma, quando comparados ao conjunto dos casamentos realizados na Madre de Deus, ou eram constrangidos, por seus senhores, a respeitarem. Essa é a tendência apresentada por grande parte dos estudos nas mais diferentes regiões.

No Rio Grande de São Pedro, os dados para Rio Pardo, entre 1758 e 1835, indicam o mesmo comportamento de respeito às interdições (PETIZ, 2020). No entanto, a sazonalidade dos casamentos de escravizados também foi correlacionada com a atividade econômica predominante, ligada à pecuária, observando-se para aquela região o aumento dos casamentos de cativos no outono e no verão, quando havia menor demanda de trabalho nas lides com o gado. Em uma área urbana como Porto Alegre, isso é mais difícil de identificar, por conta das variadas atividades exercidas, que não eram indicadas nos assentos paroquiais.

GRÁFICO 2

Casamentos (geral e dos escravizados), segundo mês de ocorrência Freguesia Nossa Senhora da Madre de Deus - 1772-1850

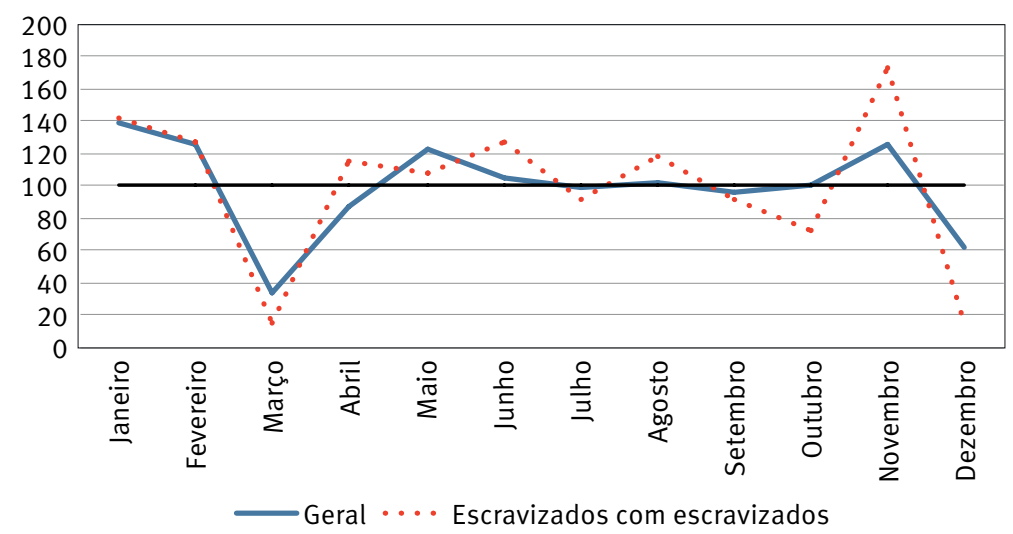

Fonte: Dados Nacaob - Madre de Deus de Porto Alegre (março 2021).

Em relação aos dias da semana escolhidos para a cerimônia, Porto Alegre também registrou diferenças entre os casais de mesma condição jurídica. Enquanto os livres uniam-se, preferencialmente, aos sábados (mais de 31\%) ou às segundas, o dia mais "escolhido" pelos escravizados (ou aquele que eles seriam "liberados de suas tarefas") era o domingo (mais de 35\%), seguido pelo sábado. Já os forros tendiam a escolher, como os livres, o sábado. Para Rio Pardo, casamentos de escravizados e de forros eram realizados, preferencialmente, às terças e aos domingos, entre 1762 e 1809, e entre 1810 e 1835 houve uma inversão, quando o domingo passou a ser o dia mais escolhido, ainda seguido da terça (PETIZ, 2020). 
TABELA 6

Casamentos, por condição jurídica dos noivos, segundo dia da semana de realização Freguesia Nossa Senhora da Madre de Deus - 1772-1850

\begin{tabular}{lccccc}
\hline Período & $\begin{array}{c}\text { Livres com } \\
\text { livres }\end{array}$ & $\begin{array}{c}\text { Forros com } \\
\text { forras }\end{array}$ & $\begin{array}{c}\text { Escravizados } \\
\text { com } \\
\text { escravizadas }\end{array}$ & Mistos & Total \\
\hline Domingo & 474 & 21 & 110 & 19 & 624 \\
Segunda & 633 & 20 & 44 & 21 & 718 \\
Terça & 335 & 15 & 38 & 16 & 404 \\
Quarta & 463 & 14 & 21 & 10 & 508 \\
Quinta & 450 & 10 & 27 & 8 & 495 \\
Sexta & 237 & 12 & 24 & & 282 \\
Sábado & 1.190 & 48 & 48 & & 1.314 \\
Total & 3.782 & 140 & 312 & 111 & 4.345 \\
\hline
\end{tabular}

Fonte: Dados Nacaob - Madre de Deus de Porto Alegre (março 2021).

Encontramos semelhanças e diferenças quando os resultados são comparados com freguesias de outras regiões brasileiras, ao longo do século XIX. Os casamentos de escravizados nas freguesias fluminenses da Candelária, São Francisco Xavier e Jacarepaguá, na primeira metade do século XIX, concentravam-se também aos sábados e domingos, argumentando-se igualmente a favor da escolha de dias que não perturbassem a rotina de trabalho (LOPES, 2006). Já para freguesias mineiras, na segunda metade do século XIX, os escravizados casavam-se, preferencialmente, às terças e aos domingos (NOGUEIRA, 2014). No caso de duas vilas paulistas, Campinas e Franca, ao longo período entre 1774 e 1888, os dias da semana preferidos eram o domingo e a segunda-feira (CUNHA; TEIXEIRA, 2014).

Por outro lado, é importante analisar as caraterísticas individuais dos cativos que se casaram na igreja da Madre de Deus, no que se refere à naturalidade, ao estado matrimonial, à cor/etnia e à legitimidade. Infelizmente nem todas essas informações foram assentadas com regularidade nos registros analisados. De toda forma, a exploração das características arroladas com mais frequência auxiliará na construção do perfil do cativo/cativa que se casou naquela localidade.

O primeiro quesito que podemos analisar é a naturalidade dos noivos e noivas. Há uma extensa literatura que, desde os anos 1980, vem estudando os padrões de casamento entre os escravizados. Muitos destes estudos analisam as nomenclaturas de origem, ou como denominamos aqui, a "naturalidade" dos nubentes escravizados (VIANA; GOMES, 2018).

Para Porto Alegre, dos 312 registros de casamentos entre escravizados, a informação sobre a nomenclatura de origem/naturalidade foi registrada para 202 noivos e 185 noivas, ou seja, há um percentual significativo de naturalidades não declaradas (35,3\% para os noivos e $40,71 \%$ para as noivas). Esse percentual está pouco abaixo do encontrado para os 539 casamentos analisados para Vassouras, entre 1828 e 1864, que somaram 45,8\% (VIANA; GOMES, 2018).

Entre os nubentes escravizados que se casaram em Porto Alegre, para os quais temos a indicação da origem, havia largo predomínio de africanos e africanas (Tabela 7). 
TABELA 7

Casamentos, segundo naturalidade dos noivos e noivas escravizados Freguesia Nossa Senhora da Madre de Deus - 1772-1850

\begin{tabular}{|c|c|c|}
\hline Naturalidade dos noivos & $\mathrm{N}$ & $\%$ \\
\hline Não declarada & 110 & 35,3 \\
\hline Naturais da África & 184 & 91,1 \\
\hline Da Costa & 55 & 27,2 \\
\hline Angola & 27 & 13,4 \\
\hline Benguela & 22 & 10,9 \\
\hline África & 20 & 9,9 \\
\hline Congo & 18 & 8,9 \\
\hline Mina & 15 & 7,4 \\
\hline Moçambique & 6 & 3,0 \\
\hline Rebolo & 6 & 3,0 \\
\hline Cabinda & 5 & 2,5 \\
\hline Nação & 4 & 2,0 \\
\hline Bajuno & 1 & 0,5 \\
\hline Cassange & 1 & 0,5 \\
\hline Guiné & 1 & 0,5 \\
\hline Monjolo & 1 & 0,5 \\
\hline Nago & 1 & 0,5 \\
\hline Ussá & 1 & 0,5 \\
\hline Naturais do Brasil & 18 & 8,9 \\
\hline Rio de Janeiro & 6 & 3,0 \\
\hline Porto Alegre & 4 & 2,0 \\
\hline Bahia & 2 & 1,0 \\
\hline Rio Grande de São Pedro & 2 & 1,0 \\
\hline Rio Grande & 1 & 0,5 \\
\hline Sabará & 1 & 0,5 \\
\hline São Paulo & 1 & 0,5 \\
\hline Viamão & 1 & 0,5 \\
\hline Total & 312 & 100,0 \\
\hline
\end{tabular}

\begin{tabular}{|c|c|c|}
\hline Naturalidade das noivas & $\mathrm{N}$ & $\%$ \\
\hline Não declarada & 128 & 41,0 \\
\hline Naturais da África & 162 & 87,6 \\
\hline Da Costa & 51 & 27,6 \\
\hline Benguela & 25 & 13,5 \\
\hline Angola & 23 & 12,4 \\
\hline África & 18 & 9,7 \\
\hline Mina & 11 & 5,9 \\
\hline Cabinda & 8 & 4,3 \\
\hline Rebolo & 8 & 4,3 \\
\hline Congo & 5 & 2,7 \\
\hline Nação & 5 & 2,7 \\
\hline Guiné & 2 & 1,1 \\
\hline Ussá & 2 & 1,1 \\
\hline Cabundá & 1 & 0,5 \\
\hline Cassange & 1 & 0,5 \\
\hline Moçambique & 1 & 0,5 \\
\hline Monjolo & 1 & 0,5 \\
\hline Naturais do Brasil & 22 & 11,9 \\
\hline Porto Alegre & 7 & 3,8 \\
\hline Rio Grande de São Pedro & 4 & 2,2 \\
\hline Bahia & 3 & 1,6 \\
\hline Pernambuco & 2 & 1,1 \\
\hline Rio de Janeiro & 2 & 1,1 \\
\hline Triunfo & 2 & 1,1 \\
\hline Santa Catarina & 1 & 0,5 \\
\hline Viamão & 1 & 0,5 \\
\hline Total & 312 & 100,0 \\
\hline
\end{tabular}

Fonte: Dados Nacaob - Madre de Deus de Porto Alegre (março 2021).

Entre os noivos, nada menos do que $91,1 \%$ deles foram identificados como "africanos" e 8,9\% eram naturais do Brasil (8, em cada 18, eram naturais do próprio Rio Grande de São Pedro). Entre as noivas a supremacia das “africanas” também foi nítida, embora pouco menor que a dos noivos escravizados. As noivas naturais da África compunham $87,6 \%$ das escravizadas que se casaram na igreja Madre de Deus de Porto Alegre. Apenas 11, $9 \%$ eram naturais do Brasil e 14, em cada 22, eram naturais do Rio Grande de São Pedro. Outros estudos também têm encontrado a supremacia dos africanos entre os escravizados que receberam as bençãos da igreja para a sua união. 
TABELA 8

Casamentos, segundo naturalidade do noivo escravizado $\mathrm{X}$ naturalidade da noiva escravizada Freguesia Nossa Senhora da Madre de Deus - 1772-1850

\begin{tabular}{|c|c|c|c|}
\hline $\begin{array}{c}\text { Naturalidade do } \\
\text { noivo }\end{array}$ & $\begin{array}{c}\text { Naturalidade da } \\
\text { noiva }\end{array}$ & $\mathbf{N}$ & $\%$ \\
\hline ND & ND & 108 & 98,2 \\
\hline ND & Porto Alegre & 1 & 0,9 \\
\hline ND & Angola & 1 & 0,9 \\
\hline África & África & 17 & 85,0 \\
\hline África & ND & 3 & 15,0 \\
\hline Angola & Angola & 17 & 63,0 \\
\hline Angola & ND & 4 & 14,8 \\
\hline Angola & Mina & 2 & 7,4 \\
\hline Angola & Rebolo & 1 & 3,7 \\
\hline Angola & Moçambique & 1 & 3,7 \\
\hline Angola & Rio de Janeiro & 1 & 3,7 \\
\hline Angola & Mina & 1 & 3,7 \\
\hline Bajuno & Nação & 1 & 100,0 \\
\hline Benguela & Benguela & 14 & 63,6 \\
\hline Benguela & Angola & 2 & 9,1 \\
\hline Benguela & Congo & 1 & 4,5 \\
\hline Benguela & Porto Alegre & 1 & 4,5 \\
\hline Benguela & Mina & 1 & 4,5 \\
\hline Benguela & ND & 1 & 4,5 \\
\hline Benguela & Da Costa & 1 & 4,5 \\
\hline Benguela & Viamão & 1 & 4,5 \\
\hline Cabinda & Cabinda & 3 & 60,0 \\
\hline Cabinda & Rebolo & 1 & 20,0 \\
\hline Cabinda & ND & 1 & 20,0 \\
\hline Cassange & Benguela & 1 & 100,0 \\
\hline Congo & Benguela & 5 & 27,8 \\
\hline Congo & Congo & 3 & 16,7 \\
\hline Congo & ND & 2 & 11,1 \\
\hline Congo & Cabinda & 2 & 11,1 \\
\hline Congo & Rebolo & 1 & 5,6 \\
\hline Congo & Pernambuco & 1 & 5,6 \\
\hline Congo & Ussá & 1 & 5,6 \\
\hline Congo & Bahia & 1 & 5,6 \\
\hline Congo & $\begin{array}{l}\text { Rio Grande de } \\
\text { São Pedro }\end{array}$ & 1 & 5,6 \\
\hline Congo & Santa Catarina & 1 & 5,6 \\
\hline Da Costa & Da Costa & 50 & 90,9 \\
\hline Da Costa & ND & 4 & 7,3 \\
\hline Da Costa & Guiné & 1 & 1,8 \\
\hline Guiné & Guiné & 1 & 100,0 \\
\hline
\end{tabular}

\begin{tabular}{|c|c|c|c|}
\hline $\begin{array}{c}\text { Naturalidade do } \\
\text { noivo }\end{array}$ & $\begin{array}{c}\text { Naturalidade da } \\
\text { noiva }\end{array}$ & $\mathrm{N}$ & $\%$ \\
\hline Mina & Mina & 5 & 33,3 \\
\hline Mina & Benguela & 3 & 20,0 \\
\hline Mina & Cassange & 1 & 6,7 \\
\hline Mina & Angola & 1 & 6,7 \\
\hline Mina & Congo & 1 & 6,7 \\
\hline Mina & Monjolo & 1 & 6,7 \\
\hline Mina & Nação & 1 & 6,7 \\
\hline Mina & ND & 1 & 6,7 \\
\hline Mina & Cabundá & 1 & 6,7 \\
\hline Moçambique & Cabinda & 2 & 33,3 \\
\hline Moçambique & ND & 1 & 16,7 \\
\hline Moçambique & Pernambuco & 1 & 16,7 \\
\hline Moçambique & Mina & 1 & 16,7 \\
\hline Moçambique & Rebolo & 1 & 16,7 \\
\hline Monjolo & ND & 1 & 100,0 \\
\hline Nação & Nação & 3 & 75,0 \\
\hline Nação & Cabinda & 1 & 25,0 \\
\hline Nago & ND & 1 & 100,0 \\
\hline Rebolo & Rebolo & 2 & 33,3 \\
\hline Rebolo & Bahia & 1 & 16,7 \\
\hline Rebolo & Benguela & 1 & 16,7 \\
\hline Rebolo & Porto Alegre & 1 & 16,7 \\
\hline Rebolo & Angola & 1 & 16,7 \\
\hline Ussá & Ussá & 1 & 100,0 \\
\hline Bahia & Bahia & 1 & 50,0 \\
\hline Bahia & Rebolo & 1 & 50,0 \\
\hline Porto Alegre & África & 1 & 25,0 \\
\hline Porto Alegre & Mina & 1 & 25,0 \\
\hline Porto Alegre & Porto Alegre & 1 & 25,0 \\
\hline Porto Alegre & Triunfo & 1 & 25,0 \\
\hline Rio de Janeiro & Porto Alegre & 3 & 50,0 \\
\hline Rio de Janeiro & Angola & 1 & 16,7 \\
\hline Rio de Janeiro & Rio de Janeiro & 1 & 16,7 \\
\hline Rio de Janeiro & $\begin{array}{l}\text { Rio Grande de } \\
\text { São Pedro }\end{array}$ & 1 & 16,7 \\
\hline Rio Grande & ND & 1 & 100,0 \\
\hline $\begin{array}{l}\text { Rio Grande de } \\
\text { São Pedro }\end{array}$ & $\begin{array}{l}\text { Rio Grande de } \\
\text { São Pedro }\end{array}$ & 2 & 100,0 \\
\hline Sabará & Rebolo & 1 & 100,0 \\
\hline São Paulo & Triunfo & 1 & 100,0 \\
\hline Viamão & Benguela & 1 & 100,0 \\
\hline
\end{tabular}

Fonte: Dados Nacaob - Madre de Deus de Porto Alegre (março 2021). 
O predomínio dos noivos e noivas "africanos" gerou um padrão de uniões fortemente endogâmico (Tabela 8). Mas a endogamia ia além do fato de ambos serem "africanos". Ao cruzarmos a origem do noivo e da noiva, percebe-se a união preferencial de naturais da África (85\%), “Da Costa” (91\%), assim como de Angola (63\%) e Benguela (63,3\%). Percebe-se a busca do parceiro(a) entre seus semelhantes.

Da mesma forma, encontramos ainda o predomínio dos que tinham como origem a África Centro Ocidental, seguramente refletindo as características de entrada dos fluxos de africanos no Rio Grande de São Pedro, no primeiro quartel do século XIX (BERUTE, 2006).

No que diz respeito à cor/etnia, temos a informação para 202 noivos e 197 noivas. Há que se lembrar de que esse dado sempre remete a categorias problemáticas. De todo modo, encontramos, como esperado, o predomínio das referências aos nubentes "pretos", já que a maioria dos escravizados que se casaram foi dado como natural da "África". Vários estudos têm associado a cor "preta" aos escravizados "naturais" da África. Para Porto Alegre, somaram 136 "pretos" e apenas 21 identificados como "pardos", enquanto para as noivas, foram 149 noivas "pretas" e 27 "pardas". Nos assentos em que registramos o quesito "cor" para ambos (noivos e noivas), 132 ambos eram "pretos" e nove eram "pardos”, refletindo também um padrão de escolha endogâmico.

Quanto ao estado matrimonial, encontramos um viúvo se casando com uma viúva e oito escravizadas viúvas casando-se em segundas núpcias. É importante ressaltar que na esmagadora maioria dos casos não se mencionou explicitamente o estado matrimonial dos nubentes escravizados. É importante chamar a atenção para a possibilidade de segundas núpcias entre escravizados: ainda que o casamento fosse de acesso muito restrito, algumas mulheres escravizadas puderam se casar novamente, opção muito mais rara entre os escravizados. Em relação à condição de legitimidade, a informação foi registrada em escassos quatro casos de escravas (uma dada como legítima e três como naturais).

Avançando na análise dos casamentos entre cativos, estudamos a senzala de dois importantes escravistas que viveram em Porto Alegre, para buscar identificar tendências que possam ser atribuídas à intervenção senhorial na realização do matrimônio de seus escravizados.

\section{A opção pelo casamento e pela prole legítima: o exemplo de duas "senzalas"}

Embora as determinações da Igreja asseverassem que os senhores não poderiam impedir o casamento de seus escravizados, está claro que a realização do casamento, de acordo com as normativas da Igreja e abençoado pelo pároco, deveria contar com algum grau de "concessão" do senhor, como também não pode ser negada a possibilidade de "negociação" entre os proprietários e escravizados, que acabavam por levar muito poucos cativos ao altar. 
Ao analisar a região Sudeste ao longo do século XIX, Slenes (1999) defendia que o apoio do proprietário era fundamental para a realização dos matrimônios, especialmente considerando que, em certos casos, era necessário realizar o deslocamento até as igrejas, que ficavam na sede dos municípios, o que poderia implicar, inclusive, a perda de horas de trabalho, se a cerimônia não fosse realizada em momentos de folga dos escravizados, aos domingos e dias santos. Há que se contar também com a burocracia exigida pela Igreja Católica para a formalização da união (SLENES, 1999, p. 93). Por essas e outras razões, o número de casamentos que envolviam nubentes escravizados era muito reduzido.

Possivelmente, em áreas urbanas, como é o caso de Porto Alegre, a questão do deslocamento poderia ter menor peso, mesmo para aqueles escravizados que viviam em propriedades nas áreas suburbanas ou rurais, em torno da capital do Rio Grande de São Pedro.

Para buscar elementos sobre as imbricações entre poder e vontade senhorial e o espectro de negociação aberto aos escravizados e escravizadas, optou-se pela identificação e análise dos proprietários dos cativos envolvidos nas cerimônias nupciais. Entre as 312 bodas que uniram escravizados, vale notar que $58 \%$ ocorreram apenas em uma oportunidade, isto é, registramos 182 senhores identificados em um único casamento entre seus escravizados. Outros 49 proprietários permitiram que dois casamentos fossem realizados entre seus cativos e cativas. Somados, conformaram $68 \%$ os proprietários que consentiram a formalização do casamento de até dois casais de cativos. Talvez esse alto percentual também se justifique pela menor dimensão das escravarias das áreas urbanas.

Seja como for, para efeito das análises iniciais, sobre esses senhores e escravizados, encontramos proprietários mencionados várias vezes nos assentos de casamentos de seus escravizados, ao longo do período estudado. Contabilizamos 18 indivíduos que permitiram a realização de, pelo menos, três matrimônios. Proprietários que registram seis ou mais casamentos nas suas senzalas foram apenas três: João Inácio Teixeira, Antônio Ferreira Leitão e Bibiano José Carneiro Fontoura. 0 “campeão” de proprietários com escravizados casados foi João Inácio Teixeira, indicado em 15 casamentos, associado a outros três casamentos, que envolviam escravizados que eram propriedade de seu irmão José Inácio Teixeira. Os irmãos foram seguidos, de longe, por Antônio Ferreira Leitão e Bibiano José Carneiro Fontoura.

A análise do conjunto de proprietários envolvidos nas mais de três centenas de matrimônios reforça que os casamentos se davam entre escravizados da mesma "senzala". A historiografia indica tendência predominante desse tipo de casamentos e Slenes (1999) apontou em seus estudos que praticamente se proibia o casamento formal entre escravizados de donos diferentes, ou entre cativos e pessoas livres.

A título de comparação, rearranjando os dados para quatro freguesias da região da fronteira oeste do Rio Grande, os casamentos entre escravizados de um único proprietário somaram 691 e os que envolviam donos diferentes corresponderam a apenas 28 . Percebe-se 
que, do total de $719,96 \%$ constituíam matrimônios que envolviam nubentes escravizados de um único senhor (PETIZ, 2020). ${ }^{11}$

Em Porto Alegre, encontramos 17 assentos que nomeiam proprietários diferentes de noivos e noivas, o que compõe apenas $5,5 \%$ do total de casamentos. Fato importante a ressaltar é que muitos dos proprietários envolvidos tinham relações de parentesco entre si, como ocorreu entre os irmãos Teixeira, mencionados anteriormente, assim como José Francisco Silveira Casado e Pedro Pires Silveira Casado (pai e filho). Além deles, temos os assentos de casamento dos escravizados que eram propriedade de André Alves Pereira Viana e José Alves Pereira Viana, para os quais não identificamos o vínculo, e o caso de Pedro José Alves de Souza e Francisco Manuel Pereira, em que a ligação de parentesco entre os proprietários não ficou sugerida com mais clareza.

Os casos de João Inácio Teixeira e Antônio Ferreira Leitão mereceram análise mais detalhada de suas escravarias, pois, além de serem “os campeões” de proprietários de escravizados que se casaram, dedicaram-se a atividades econômicas diferentes: João foi um importante comerciante em Porto Alegre e Antônio foi um rico estancieiro. Acompanhando os assentos de escravizados nos quais eles foram identificados como proprietários, vimos que João batizou 41 cativos e Antônio 35, estando no restrito rol de proprietários que batizaram mais de 25 escravizados e entre aqueles que mais batizaram escravizados legítimos. Contrariamente, ambos não figuram na lista dos escravistas que mais batizaram escravizados naturais. Esses dados poderiam indicar estratégias senhoriais diferentes para permitir o acesso dos cativos ao matrimônio?

Analisemos, inicialmente, o caso dos irmãos João Inácio Teixeira e José Inácio Teixeira, proprietários que casaram o maior número de escravizados entre si. Parece ter sido uma "política" implementada nas senzalas de ambos. De fato, os irmãos tiveram parte em casamento coletivo, realizado em 24 de abril de 1803, envolvendo 14 casais, sendo que em 13 deles João era proprietário do noivo e de uma noiva e José era proprietário de 13 noivas e de um noivo. Não é possível determinar o que levou os irmãos a decidir por esse casamento coletivo. Mais curioso é verificar que houve uma escolha de cada um deles ceder, preferencialmente, o noivo ou a noiva e, muitos desses casais, nos anos seguintes, terão filhos legítimos registrados na igreja da Madre de Deus.

Ao longo do período que acompanhamos a trajetória de João e José em Porto Alegre, registramos 41 batizados de escravizados pertencentes a ambos, que eram legítimos, envolvendo 27 casais diferentes. Desses 27 , só oito deles estavam entre os casais que tiveram seu casamento realizado na Madre de Deus. Os irmãos Teixeira, além de atuarem no comércio e no tráfico de escravizados, eram proprietários de uma frota de navios, desempenhando papel importante em Porto Alegre até a morte de João, em 1824 (SCHIERHOLT,

\footnotetext{
11 Vale notar que as informações arroladas por Silmei Petiz analisam o conjunto de casamentos que unem não apenas nubentes escravizados, mas todos os que envolviam ao menos um nubente escravizado, não considerando, como foi feito aqui, apenas os casamentos entre escravizados. Nesse caso, levando em conta todos os casamentos, Petiz encontrou que mais de $70 \%$ das uniões se davam entre escravizados pertencentes ao mesmo proprietário e escassos $3 \%$ se faziam entre escravizados de diferentes senhores.
} 
2002, p. 17). Ambos tinham propriedade fora de Porto Alegre, obtida por meio de sesmaria nas terras do vale do Taquari, onde fundaram a fazenda da Estrella. É possível que parte dos escravizados estivesse alocada nessa propriedade, o que poderia levar os assentos a serem registrados em outra igreja.

O caso do capitão Antônio Ferreira Leitão é bastante ilustrativo de como os mecanismos de reprodução dos cativos poderiam variar em função das “vontades”, das “determinações" e até mesmo dos "princípios morais" dos escravistas. Antônio foi o senhor que casou muitos cativos de suas escravarias. Como resultado da "política" implantada em sua senzala, ele foi não apenas um dos indivíduos que mais batizaram cativos, mas também o proprietário da senzala onde se batizou o maior número de escravizados "legítimos", entre os finais do século XVIII e primeira década do XIX. Por meio dos assentos de batismo de escravizados, não registramos também a compra de escravizados maiores de dez anos, como ocorreu com outros escravistas que viveram em Porto Alegre. Parece que, de fato, ele privilegiava a reprodução endógena e legítima. Reforçando essa hipótese, como vimos, ele não foi listado entre os escravistas que mais batizaram crianças escravas naturais. ${ }^{12}$

\section{Considerações finais}

Para finalizar, retomamos as considerações sobre o regime demográfico das áreas urbanas e das populações escravas. Sem dúvida, fica muito claro, como sugere Nadalin, que, entre a população cativa, as possibilidades postas pelo casamento e a própria formação da família escrava estavam intimamente ligadas às características demográficas da população escravizada, assim como às vontades e aos constrangimentos impostos pelos senhores de cada uma das senzalas analisadas, comprovando, pelos exemplos de alguns escravistas, que o matrimônio estava submetido à vontade/interesse do senhor em estimular ou, pelo menos, não colocar obstáculos ao casamento dos seus escravizados. Isso ocorreu também nas escravarias de uma área urbana como Porto Alegre.

Além de comprovar os baixos índices de nupcialidade entre os escravizados, o caso portoalegrense também mostrou com clareza o impacto do tráfico nos indicadores demográficos, sobretudo a questão da queda vertiginosa da fecundidade legítima, que começa em pouco mais de $27 \%$, no início do período analisado, caindo para 5,5\% nos anos finais, o que parece ser resultado direto da crescente entrada de escravizados adultos, via tráfico, que se intensificou por volta de 1815.

Por outro lado, observou-se também que o estudo da fecundidade entre os escravizados merece um investimento mais consequente dos pesquisadores, pois tivemos indícios claros de políticas senhoriais que apostavam e incentivavam a reprodução endógena também em área urbana. Contudo, esse era um comportamento minoritário, já que a maioria dos

\footnotetext{
${ }^{12} \mathrm{O}$ caso desse proprietário foi analisado de forma aprofundada no artigo "Casamento e compadrio na casa-grande e na senzala: a família e a escravaria do Capitão Antônio Ferreira Leitão (Porto Alegre - finais do século XVIII a meados do XIX)”, artigo aceito para publicação em História Unisinos.
} 
escravizados batizados em Porto Alegre era composta por "naturais". Além disso, e como indicou Marcílio (1984), o crescimento vegetativo entre os escravizados não garantia a sua reposição, sendo necessários, para a renovação da mão de obra escravizada, os aportes do tráfico. Isso também ocorreu em Porto Alegre. A análise da população escravizada de Porto Alegre mostrou que o crescimento vegetativo, desde o início do século XIX até 1872, foi negativo (SCOTT, 2020, p. 84 e seg.). Ainda que houvesse, em algumas senzalas, o incentivo à reprodução endógena e, eventualmente, legítima, ela não teve papel decisivo. Talvez essa estratégia fosse usada pelos proprietários como uma forma de concessão, para beneficiar uns escravizados em detrimento de outros.

De todo modo, e para terminar com uma provocação, os dados nos fazem pensar se eram tão diferentes, comparados às regiões de plantations, os comportamentos dos escravistas e dos escravizados que viveram em uma localidade com características urbanas, como Porto Alegre, no período estudado.

\section{Referências}

BERUTE, G. S. Dos escravos que partem para os portos do sul: características do tráfico negreiro do Rio Grande de São Pedro do Sul, c. 1795 - c. 1825. Dissertação (Mestrado) - Universidade Federal do Rio Grande do Sul (UFRGS), Porto Alegre, 2006.

BRÜGGER, S. M. J. Legitimidade, casamento e relações ditas ilícitas em São João Del Rei (1730-1850). In: DE PAULA, J. A. et al. (ed.). Anais do IX Seminário sobre a Economia Mineira. Belo Horizonte: Cedeplar, Universidade Federal de Minas Gerais (UFMG), 2000. v. 1, p. 37-64. Disponível em: https://ideas.repec.org/h/cdp/diaman/200002.html. Acesso em: mar. 2021.

BRÜGGER, S. M. J. Minas patriarcal. Família e sociedade (São João del Rei - séculos XVIII e XIX). São Paulo: Annablume, 2007.

CHAVES, A. J. G. Memórias ecônomo-políticas sobre a administração pública do Brasil. 4. ed. São Leopoldo (RS), 2004 [1822].

CUNHA, M. F.; TEIXEIRA, P. E. "Se receberão em matrimônio": o casamento de cativos em duas vilas paulistas. In: VI CONGRESO DE LA ASOCIACIÓN LATINOAMERICANA DE POBLACIÓN. Anais [...]. Lima: Alap, 2014.

CUNHA, M. F. Demografia e família escrava. Franca-SP, século XIX. Tese (Doutorado) Universidade Estadual de Campinas (Unicamp), Campinas, 2009.

CUNHA, M. F. Fogos e escravos da Franca do Imperador no século XIX. Dissertação (Mestrado) - Universidade Estadual de Campinas (Unicamp), Campinas, 2005.

CUNHA, M. F. Uma reflexão sobre os regimes demográficos da escravidão. In: XVIII ENCONTRO NACIONAL DE ESTUDOS POPULACIONAIS. Anais [...]. Águas de Lindóia/SP: Abep, 2012. Disponível em: http://www.abep.nepo.unicamp.br/xviii/anais/files/909.pdf.

FARIA, S. C. A colônia em movimento. Fortuna e família no cotidiano colonial. Rio de Janeiro: Nova Fronteira, 1998.

FARIA, S. C. Família escrava e legitimidade. Estratégias de preservação da autonomia. Estudos Afro-Asiáticos, n. 23, 1992. 
FREIRE, J. Escravidão e família escrava na zona da mata mineira oitocentista. Tese (Doutorado) - Universidade Estadual de Campinas (Unicamp), Campinas, 2009.

FREIRE, J. Família, legitimidade e família em uma freguesia escravista da zona da mata mineira, século XIX. Lócus - Revista de História, v. 11, n. 1-2, p. 51-73, 2005.

GOMES. L. C. Uma cidade negra: escravidão, estrutura econômico-demográfica e diferenciação social na formação de Porto Alegre, 1772-1802. Dissertação (Mestrado) - Universidade Federal do Rio Grande do Sul (UFRGS), Porto Alegre, 2012.

KREAGER, P. Demographic regimes as cultural systems. In: COLEMAN, D.; SCHOFIELD, R. (ed.). The state of population theory. New York: Basil Blackwell Ltd., 1986.

KÜHN, F. Gente da fronteira: família, sociedade e poder no sul da América Portuguesa - século XVIII. Tese (Doutorado) - Universidade Federal do Rio Grande do Sul (UFRGS), Porto Alegre, 2006.

KÜHN, F. Breve história do Rio Grande do Sul. 2. ed. Porto Alegre: Leitura XXI, $2004 a$.

LIMA, C. A. M. A ilegitimidade escrava no centro sul brasileiro na primeira metade do século XIX. In: 60 ENCONTRO ESCRAVIDÃO \& LIBERDADE NO BRASIL MERIDIONAL. Anais [...]. Florianópolis: Grupo de Pesquisa CNPq, 2013. Disponível em: http://www.escravidaoeliberdade.com.br/site/ images/Textos.6/carloslima.pdf.

LOPES, J. C. P. Casamentos de escravos nas freguesias da Candelária, São Francisco Xavier e Jacarepaguá: contribuições aos padrões de sociabilidade matrimonial no Rio de Janeiro (c.1800-c.1850). Dissertação (Mestrado em História Social) - Universidade Federal do Rio de Janeiro (UFRJ), Rio de Janeiro, 2006.

MARCÍLIO, M. L. Sistemas demográficos no Brasil do século XIX. In: MARCÍLIO, M. L. População e sociedade. Evolução das sociedades pré-industriais. Petrópolis: Vozes, 1984. p. 193-207.

MOREIRA, P. R. S.; PINTO, N. G. Negro não se casa: um balanço da historiografia sobre a família escrava no Rio Grande do Sul. In: SCOTT, A. S. V. et al. (org.). História da família no Brasil meridional. Temas e perspectivas. São Leopoldo: Oikos/Editora Unisinos, 2014. p. 40-74.

MOURA FILHO, H. P. Demografia histórica do Rio de Janeiro na segunda escravidão. Tese (Doutorado) - Universidade Federal do Estado do Rio de Janeiro (Unirio), Rio de Janeiro, 2021.

NADALIN, S. A população no passado colonial brasileiro: mobilidade versus estabilidade. Topoi - Revista de História, Rio de Janeiro, v. 4, n.7, p. 222-275, jul./dez. 2003.

NADALIN, S. O. História e demografia: elementos para um diálogo. Campinas: Abep, 2004.

NADALIN, S. O. Questões referentes aos regimes demográficos no passado colonial brasileiro. In: SCOTT, A. S. V; BERUTE, G. S.; MATOS, P. T. (org.). Gentes das ilhas. Trajetórias transatlânticas dos Açores ao Rio Grande de São Pedro, entre as décadas de 1740 e 1790. São Leopoldo-RS: Oikos Editora, 2014.

NOGUEIRA, L. F. V. Com as bençãos da igreja: casamentos de escravos em freguesias mineiras na segunda metade do século XIX. Locus - Revista de História, Juiz de Fora, v. 20, n. 1, p. 305326, 2014.

PAIVA, E. F. Dar nome ao novo. Uma história lexical da Ibero-América entre os séculos XVI e XVIII (as dinâmicas de mestiçagens e o mundo do trabalho). Belo Horizonte: Autêntica Editora, 2015.

PERUSSATTO, M. K. Como se de ventre livre nascesse. Experiências de cativeiro, parentesco, emancipação e liberdade nos derradeiros anos da escravidão - Rio Pardo/RS, c. 1860 - c. 1888. Dissertação (Mestrado) - Universidade do Vale do Rio dos Sinos (Unisinos), São Leopoldo, 2010. 
PESAVENTO, S. J. Memória Porto Alegre: espaços e vivências. Porto Alegre: Editora da UFRGS, 1999.

PESAVENTO, S. J. Uma certa Revolução Farroupilha. In: GRINBERG, K.; SALLES, R. (org.). 0 Brasil Imperial, 1831-1870. Rio de Janeiro: Civilização Brasileira, 2009. v. II, p. 233-268.

PETIZ, S. S. Caminhos cruzados. Famílias e estratégias escravas na fronteira oeste do Rio Grande de São Pedro (1750-1835). São Paulo: Baraúna, 2020.

RIBEIRO, M. R. P. Estratégias indígenas na fronteira meridional: os guaranis missioneiros após a conquista lusitana (Rio Grande de São Pedro, 1801-1834). Dissertação (Mestrado) - Universidade Federal do Rio Grande do Sul (UFRGS), Porto Alegre, 2013.

ROWLAND, R. População, família, sociedade: Portugal, séculos XIX-XX. 2. ed. revista e aumentada. Oeiras: Celta Editora, 1997.

SCHIERHOLT, A. J. Estrela ontem e hoje. 2. ed. Lajeado, 2002.

SCHWARTZ, S. B. Segredos internos. Engenhos e escravos na sociedade colonial, 1550-1835. São Paulo: Companhia das Letras, 1988.

SCOTT, A. S. V.; SCOTT, D. Casamentos entre desiguais no Brasil Meridional (1772-1845). In: GHIRARDI, M.; SCOTT, A. S. V. (coord.). Familias históricas: interpelaciones desde perspectivas Iberoamericanas a través de los casos de Argentina, Brasil, Costa Rica, España, Paraguay y Uruguay. São Leopoldo-RS: Oikos; Editora Unisinos, 2015. p. 37-79.

SCOTT, A. S. V. Sobre os espaços de sociabilidades a partir do cruzamento nominativo de fontes eclesiásticas. In: DORÉ, A.; SANTOS, A. C. de A. (org.). Temas setecentistas. Governos e populações no império português. Curitiba: UFPR-SCHLA/Fundação Araucária, 2009. p. 413-427.

SCOTT, D. Livres e escravos: população e mortalidade na Madre de Deus de Porto Alegre (17721872). Tese (Doutorado) - Universidade Estadual de Campinas (Unicamp), Campinas, 2020.

SLENES, R. W.; FARIA, S. C. Família escrava e trabalho. Tempo, v. 3, n. 6p. 1-7, 1998.

SLENES, R. W. Escravidão e família: padrões de casamento e estabilidade familiar numa comunidade escravista (Campinas, século XIX). Estudos Econômicos, v. 17, n. 2, p. 217-227, 1987.

SLENES, R. W. Na senzala uma flor: esperanças e recordações na formação da família escrava - Brasil, Sudeste, século XIX. Rio de Janeiro: Nova Fronteira, 1999.

SOUZA, C. F.; MÜLLER, D. M. Porto Alegre e sua evolução urbana. 2. ed. Porto Alegre: Editora da UFRGS, 2007.

TOMICH, D. Apresentação. In: MUAZE, M.; SALLES, R. H. (org.). A segunda escravidão e o império do Brasil em perspectiva histórica. São Leopoldo: Casa Leiria, 2020.

VIANA, I.; GOMES, F. Das dimensões atlânticas: notas sobre demografia escrava no Rio de Janeiro, Vassouras, c. XIX. Revista Historiar, v. 10, n. 18, p.38-57, jan.-jun. 2018.

VIANA, I. S.; GOMES, F. S. Fazendo gênero na plantation. Notas sobre casamentos de africanos em Cuba e no Brasil, nos séculos XVIII e XIX. Acervo, v. 33, n. 1, p. 20-39, jan.-abr. 2020.

VIDE, S. M. Constituições Primeiras do Arcebispado da Bahia. Brasília: Senado Federal, 2011.

XAVIER, R. C. L. et al. História da escravidão no Brasil meridional: guia bibliográfico. Porto Alegre: Editora da UFRGS, 2007. 


\title{
Sobre os autores
}

Ana Silvia Volpi Scott é doutora em História e Civilização pelo Instituto Universitário Europeu (Florença/Itália). Professora Doutora MS3.1 do IFCH da Universidade Estadual de Campinas (Unicamp). Pesquisadora do Núcleo de Estudos de População “Elza Berquó” (Nepo/Unicamp). Pesquisadora $1 \mathrm{C}$ do CNPq.

Dario Scott é doutor em Demografia pela Universidade Estadual de Campinas (Unicamp).

\section{Endereço para correspondência}

\author{
Ana Silvia Volpi Scott \\ Av. Albert Einstein, 1300, Cidade Universitária "Zeferino Vaz" \\ 13083-852 - Campinas-SP, Brasil \\ Dario Scott \\ Alameda Carlos Barduchi, 865, Dois Córregos \\ 13278-170 - Valinhos-SP, Brasil
}

\begin{abstract}
Between constraint and desire: marriage between enslaved people in Porto Alegre (1772-1850)

Studies on slavery have shown that access to marriage among captives was far from the norm. In fact, even for the free population, some men and women would never have their union formalized. Here we explore the minority universe of marriages between enslaved people held in the parish of Nossa Senhora da Madre de Deus in Porto Alegre, Captaincy-Province of Rio Grande de São Pedro, between 1772 and 1850, in order to discuss the issue of restricted demographic regimes, an important issue on the agenda of Brazilian Historical Demography. The main sources are parish records of marriages, baptisms, and deaths of enslaved people, analyzed from an aggregate perspective - profile of spouses, birthplace, (il)legitimacy - as well as through the study of some owners of captive couples who had their marriage recorded in the parish. The results confirm the limited access of slaves to formalized marriage. It also points to the impact of trafficking on demographic indicators, especially the significant drop in legitimate fertility, with the entry of adult slaves, especially as of the second decade of the 19th century. Finally, we analyzed two "senzalas", to exemplify slaveholder's policies which encouraged marriage and endogenous reproduction.
\end{abstract}

Keywords: Slavery. Demographic regime. Record linkage. Marriage. (II)legitimacy.

\section{Resumen}

Entre limitaciones y voluntades: casamientos entre esclavizados en Porto Alegre (1772-1850)

Los estudios sobre la esclavitud han demostrado que el acceso al matrimonio entre los cautivos estaba lejos de ser la regla. De hecho, incluso para la población libre, gran parte de hombres y mujeres nunca formalizarían su unión. Aquí, el universo minoritario de los matrimonios entre esclavos realizados en la parroquia de Nossa Senhora da Madre de Deus en Porto Alegre, 
Capitanía-Provincia de Rio Grande de São Pedro, entre 1772 y 1850, se explora como lema para discutir el tema de regímenes demográficos restringidos, de importancia en la agenda de la Demografía histórica brasileña. Las principales fuentes son los registros parroquiales de matrimonios, bautismos y muertes de esclavos, analizados desde una perspectiva agregada - perfil del prometido, lugar de nacimiento, (i)legitimidad-, así como a través del estudio de dos senzalas de propietarios que permitieron el matrimonio de esclavizados. Los resultados confirman el acceso limitado de los esclavos al matrimonio formalizado. También señala el impacto del tráfico en los indicadores demográficos, especialmente la muy significativa caída de la fecundidad legítima, con la entrada de esclavos adultos, especialmente a partir de la segunda década del siglo XIX. Finalmente, analizamos dos barrios de esclavos para ejemplificar las políticas señoriales que fomentaron el matrimonio y la reproducción endógena.

Palabras clave: Esclavitud. Régimen demográfico. Cruce de fuentes. Matrimonio. (I)legitimidad

Recebido para publicação em 12/04/2021

Aceito para publicação em 02/06/2021 